\title{
Learning and Working Memory In Mice Under Different Lighting Conditions
}

\author{
Aprendizado e Memória de Trabalho em Camundongos sob Diferentes Condiçóes de Iluminação
}

\author{
Shayenne Elizianne Ramos ${ }^{1}$, Luis David Solis Murgas', Monica Rodrigues \\ Ferreira $^{3}$, Carlos Alberto Mourao-Junior ${ }^{4}$
}

\begin{abstract}
Objective. This study aimed to investigate the effect of different light/ dark cycles and light intensity during behavioral tests of learning and working memory in Swiss mice. Method. Fifty-seven Swiss mice were kept in a housing room in either a 12:12h light/dark cycle (LD), constant light (LL), or constant darkness (DD). The animals were then tested in Lashley maze and Object recognition task under either 500 or 0 lux illumination, resulting in six treatments (LD-500, LD-0, LL500, LL-0, DD-500, and DD-0). Results. There were no significant differences between the conditions of light/dark, or between tests at 500 and 0 lux. Animals kept in constant darkness and tested at 0 lux (DD-0) had learning and working memory impaired, as demonstrated by slower learning in Lashley III maze, and no object recognition in Object recognition task. Conclusion. Continuous darkness throughout the experiment affected the learning and working memory of Swiss mice.
\end{abstract}

Keywords. Circadian Rhythms, Working Memory, Cognition.

Citation. Ramos SE, Murgas LDS, Ferreira MR, Mourao-Junior CA. Learning and Working Memory In Mice Under Different Lighting Conditions.

\section{RESUMO}

Objetivo. Investigar o efeito de diferentes ciclos claro/escuro e da intensidade luminosa durante testes comportamentais de aprendizagem e memória de trabalho em camundongos suíços. Método. Cinquenta e sete camundongos foram mantidos em um biotério nas seguintes condiçōes: 12:12h de ciclo claro/escuro (LD), luz constante (LL), ou escuridão constante (DD). Os animais foram, então, testados no labirinto de Lashley e no teste de reconhecimento de objetos sob 500 ou 0 lux de iluminação, resultando em seis grupos (LD-500, LD-0, LL-500, LL-0, DD-500 e DD-0). Resultados. Não houve diferenças significativas entre as condiçôes de luz ou escuridão, ou na iluminação entre 500 e 0 lux nos testes. Animais mantidos em constante escuridão e testados a 0 lux (DD-0) tiveram a aprendizagem e a memória de trabalho prejudicadas, como demonstrado pelo aprendizado lento no labirinto Lashley, e ausência do reconhecimento de objetos na tarefa de reconhecimento de objetos. Conclusáo. O escuro contínuo durante todo o experimento afetou o aprendizado e a memória de trabalho em camundongos.

Unitermos. Ritmos Circadianos, Memória de Trabalho, Cognição.

Citaçáo. Ramos SE, Murgas LDS, Ferreira MR, Mourao-Junior CA. Aprendizado e Memória de Trabalho em Camundongos sob Diferentes Condiçóes de Iluminação.

\footnotetext{
Trabalho realizado na Universidade Federal de Juiz de Fora, Juiz de Fora-MG, Brasil.

1.Bióloga, Mestre em Ciências Biológicas, Universidade Federal de Juiz de Fora, Juiz de Fora-MG, Brasil.

2.Veterinário, Doutor em Zootecnia, Universidade Federal de Lavras, Lavras-MG, Brasil.

3.Veterinária, Doutora em Ciência Animal, Universidade Federal de Lavras, Lavras-MG, Brasil.

4.Médico, Doutor em Endocrinologia, Universidade Federal de Juiz de Fora, Juiz de Fora-MG, Brasil.
} 


\section{INTRODUCTION}

The circadian system modulates many behavioral and physiological processes ${ }^{1,2}$. There is evidence that this circadian variation may be a general feature of the performance of animals in learning and memory tasks ${ }^{3,4}$. For example, Long-Evans rats had impaired memory when subjected to disruption of circadian rhythms caused by phase shifts ${ }^{5}$. The day length induce changes in learning and memory in White-footed mice ${ }^{6}$ and in C-57/6J and $\mathrm{C} 3 \mathrm{H}$ mice learned better during the light phase than in the dark phase ${ }^{3}$.

However, the mechanisms underlying the circadian interference with cognitive functions are unknown. Many physiological processes which exhibit circadian variations, such as hormone secretions, could be the basis of these changes ${ }^{3}$. Melatonin, for example, has been shown to act as a modulator of particular cognitive functions ${ }^{7-10}$.

As circadian rhythms are associated with the lighting environment, the effects on organisms caused by manipulations of lighting should be considered. Light exposure during the post-natal period of mice causes structural and neurochemical changes (protein expression and other changes in cells) in the suprachiasmatic nucleus, this may affect clock function, which may in turn modify animal behavior ${ }^{11}$.

Therefore, we emphasize the importance of understanding the effects caused by ambient lighting upon animal behavior. As Swiss mice exhibit neophilic behavior $^{12,13}$, these animals are convenient and appropriate for studies investigating aspects of cognition. However, there have been no studies correlating light with learning and working memory in these animals, thus our hypothesis is that changes in lighting can impair these cognitive processes. Hence, this study aimed to analyze the effect of different light/dark cycles in the housing room, as well as light intensity, during behavioral tests of learning and working memory in Swiss mice.

\section{METHOD}

\section{Animals}

Fifty-seven Swiss adult male mice (90 days old, weight $45 \mathrm{~g}$ ) were evaluated in this study. The mice were supplied by Reproductive Biology Center of Federal University of Juiz de Fora (CBR/UFJF). Eight to 10 animals were housed in groups, in plastic cages ( $41 \times 34 \times 16 \mathrm{~cm})$ with aspen chip bedding, and they were kept in the housing room in Physiology Laboratory of UFJF.

The mean temperature was $20.51 \pm 2.48 \mathrm{C}$ and the mean humidity was $68.31 \pm 6.53 \%$, recorded with a digital thermohygrometer throughout the experiment. The animals were maintained for a week in the housing room to habituate ${ }^{14}$, with water and food ad libitum, and under a normal 12:12h light/dark cycle (lights on 7:00h).

All experimental procedures were approved by Ethics Committee on Animal Experimentation of Federal University of Juiz de Fora (protocol number 043/2009), and were consistent with the principles stated in Guide for care and use of laboratory animals ${ }^{15}$.

\section{Experimental Procedure}

\section{Treatments}

After the habituation period in the housing room, the mice were divided into three groups with, respectively, 17, 20, and 20 animals. Each group received a consistent set of light/dark cycles in the housing room, maintained throughout the experiment: the Light-Dark group (LD) was maintained in a $12: 12 \mathrm{~h}$ light/dark cycle; the Light-Light group (LL) was subjected to constant light of around 25 lux, and the Dark-Dark group (DD) was maintained in constant darkness.

Four days later, the behavioral tests were started and performed in a room next to the housing room. Each group was subdivided into two subgroups according to the light intensity at the time of testing: 500 or 0 lux (measured at the center of the apparatus). This procedure resulted in six treatments: LD-500, LD-0, LL-500, LL-0, DD-500 and DD-0 with nine, eight, 10, 10, 10, and 10 mice, respectively. The letters of each treatment indicate the light/dark cycles in the housing room, and the number represents the light intensity during the test.

The 500 lux illumination was selected based on the light intensity of the laboratory rooms. Fluorescent lamps were used to maintain this illumination during the light phase in the housing room. For the condition of total darkness (0 lux), both in the housing room and in the test room, the lights were kept off and black plastic sheets were used on the windows. A red lamp was used for observations at 0 lux. All measurements were record- 
ed with a lux digital meter. All procedures were recorded by a video camera, and the researcher who carried out the analysis was blind about the groups to which each animal belonged.

The animals from each treatment were tested in Lashley III maze for analysis of learning. Then there was a break of two days, during which time the mice were kept in the housing room in the light/dark cycle established for each treatment. Subsequently, the animals were submitted to the object recognition task to assess working memory. Behavioral tests were recorded using a digital video camera, and tests were always performed at the same time, between 19:00 and 00:00 h, since mice have a normal period of nocturnal activity.

\section{Lashley Maze}

The maze was a mouse scale version of Maze III described by Karl Lashley ${ }^{16}$. It was made of wood and consisted of a start box, four interconnected alleys, and a goal box. Each alley had dimensions of $58 \times 6 \times 16 \mathrm{~cm}$, and included a port $6 \mathrm{~cm}$ wide (Figure 1).

The learning test consisted of subjecting each mouse to one trial per day in the maze for five consecutive days, always at the same time. During the trial, each animal was placed in the start box, with its head facing the door, and allowed to traverse the maze until it reached the goal box. The run time, from placement in the start box to entering the goal box, was manually timed with a digital stop-clock; a cut-off time of five minutes was imposed, after which the mouse was guided to the goal box. After each trial, the mice were removed from the maze,

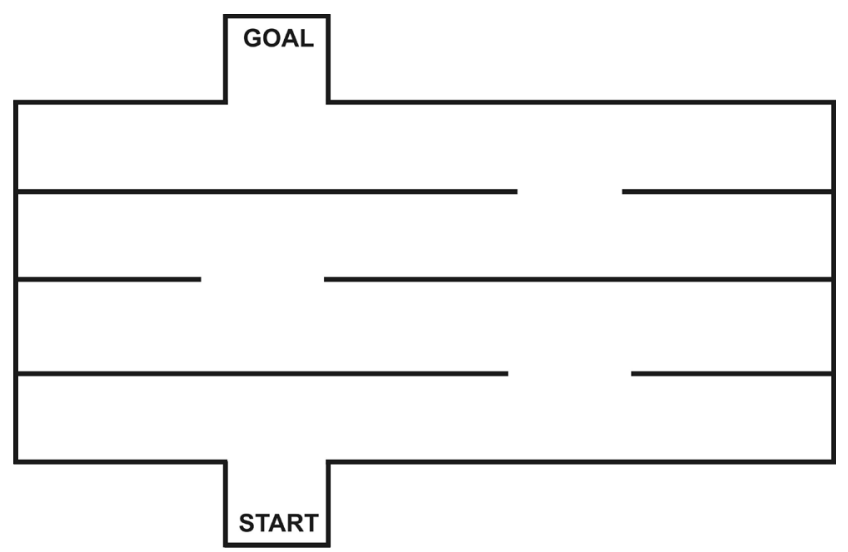

Figure 1. Lashley III maze, showing the start and the goal compartments and the four alleys. put back in their cages and returned to the light/dark cycle in the housing room. At this time, the maze was cleaned with $70 \%$ isopropyl alcohol to eliminate odors left by the animals which could influence their behavior.

Learning by the animals was assessed by the number of errors in each trial. It was considered an error when the mouse turned the opposite way or didn't come through the door, both resulting in a "cul-de-sac"; the errors were only counted when the animal was moving toward the goal box ${ }^{16}$.

\section{Object Recognition Task (ORT)}

Working memory was assessed by the object recognition task $\mathrm{k}^{12}$. The test was conducted in a rectangular field $(60 \times 40 \mathrm{~cm})$, covered with a glass anti-skid floor and with walls $30 \mathrm{~cm}$ in height. The objects were four plastic cylinders, $3 \mathrm{~cm}$ in diameter and $5 \mathrm{~cm}$ in height. Three objects were white and identical $\left(A_{1}=A_{2}=A_{3}\right)$, and one was black (B).

The animals were placed on the field for five minutes to habituate. Twenty-four hours after habituation, a training session was performed. Each mouse was placed on the field, with his face to the wall, in the presence of white cylinders $A_{1}$ and $A_{2}$ (commonly referred to as the "sample object"), to be familiarized for five minutes. After this session, the animal was removed from the field and kept in a cage for 30 seconds in the test room. After 30 seconds, the animal was returned to the field with white cylinder $A_{3}$ (equal to cylinders $A_{1}$ and $A_{2}$, the previously experienced sample objects) and black cylinder $\mathrm{B}$ (novel object) for five minutes, and working memory was evaluated.

The time the animals spent exploring the objects $A_{3}\left(T_{A}\right)$ and $B\left(T_{B}\right)$ was recorded with a digital stop-clock. Object recognition was distinguished by the animal spending more time exploring the novel object (B). The behavior was considered exploring when the animal sniffed or touched the object with his nose or paws. Then, the discrimination index was calculated according to formula ${ }^{12}$ :

$$
\left(\frac{T_{B}}{T_{A}+T_{B}}\right)
$$

Object $\mathrm{A}_{3}$ was used to prevent the animal from using olfactory cues for recognition. Between tests, the 
field and objects were cleaned with 70\% isopropyl alcohol and, after the ORT and habituation, the animals were returned to their light/dark cycle in the housing room.

\section{Statistical Analysis}

To evaluate learning of the route in Lashley III maze over five days, the number of errors per day was subjected to an analysis of variance for repeated measures (r-ANOVA) for each of the six treatments. Additionally, a paired test $t$ was performed to check if the number of errors was significantly reduced between the first day, without a previous trial, and the fifth day of testing, after four trials. Before performing these tests we ensure that there was no significant interaction suggesting that the effect of time (days) could interfere with the effect of light (group). Such interaction has been rejected by a preliminary two-way r-ANOVA $\left(\mathrm{F}_{(12,132)}=.701, p=.748\right)$.

Analyzing the effects of different conditions of light/dark cycle in the housing room, the number of errors on the fifth day was subjected to analysis of variance (ANOVA) between treatments LD-500, LL-500, and DD-500, and next between treatments LD-0, LL-0, and DD-0. Between treatments LD-500 and LD-0 was made test $\mathrm{t}$ to analyze light intensity during the test in the maze. In all analyses the level of significance was set at $5 \%$.

To evaluate working memory, the discrimination index values were submitted to descriptive analysis, and considered verified if the index was higher than .5 , that is, if the animal remembered the object ${ }^{12}$. All analyses were performed using Statistica version 7 software.

\section{RESULTS}

\section{Lashley III maze}

There was a significant reduction in errors over the five days of testing mice receiving treatments LD-500, LD-0, LL-500, LL-0, and DD-500, but in the case of treatment DD-0 this reduction throughout the test wasn't significant. Conversely, the mean number of errors for all the treatments on the fifth day was significantly lower than on the first day of testing, indicating that there was learning (Table 1, Figure 2).

Regarding the effect of different conditions of light/dark cycle in the housing room, there weren't sta- tistically significant differences between treatments LD500, LL-500, and DD-500 $\left(\mathrm{F}_{(2,25)}=1.87, p=.176\right)$ or between treatments LD-0, LL-0, and DD-0 $\left(\mathrm{F}_{(2,26)}=1.80\right.$, $p=.185$ ). Likewise, there wasn't a significant effect of light intensity during the test between treatments LD-500 and LD-0 $\left(\mathrm{t}_{(15)}=-.89, p=.39\right)$.

Table 1

Results of analysis of variance for repeated measures ( $r-A N O V A)$ and paired $t$ test for treatments $L D-500, L D-0, L L-500 L L-0, D D-500$, and DD-O in the Lashley III maze. ${ }^{*} p<.05, n=$ number of individuals

\begin{tabular}{ccc}
\hline Treatment & r-ANOVA & Paired t-test \\
\hline LD-500 $(\mathrm{n}=8)$ & $\mathrm{F}_{(4,28)}=5.50, p=.002^{*}$ & $\mathrm{t}_{(7)}=3.86, p=.006^{*}$ \\
LD-0 $(\mathrm{n}=9)$ & $\mathrm{F}_{(4,32)}=3.46, p=.019^{*}$ & $\mathrm{t}_{(8)}=3.01, p=.017^{*}$ \\
LL-500 $(\mathrm{n}=10)$ & $\mathrm{F}_{(4,36)}=5.27, p=.002^{*}$ & $\mathrm{t}(9)=2.99, p=.015^{*}$ \\
LL-0 $(\mathrm{n}=10)$ & $\mathrm{F}_{(4,36)}=5.85, p=.01^{*}$ & $\mathrm{t}_{(9)}=3.81, p=.004^{*}$ \\
DD-500 $(\mathrm{n}=10)$ & $\mathrm{F}_{(4,36)}=6.77, p<.001^{*}$ & $\mathrm{t}_{(9)}=4.53, p=.001^{*}$ \\
DD-0 $(\mathrm{n}=10)$ & $\mathrm{F}_{(4,36)}=1.87, p=.137$ & $\mathrm{t}_{(9)}=3.76, p=.004^{*}$ \\
\hline
\end{tabular}

\section{Object Recognition Task}

Only treatment DD-0 failed to attain a discrimination index above .5 , indicating that the animals receiving this treatment didn't recognize the object $A_{3}$, since they spent more time exploring this sample object compared to novel object $\mathrm{B}$. The opposite could be observed for the other treatments that had discrimination indices greater than .5 (Table 2).

\section{DISCUSSION}

Only animals receiving treatment DD-0, which were kept in constant darkness and tested at 0 lux, had their learning and working memory impaired. The learning of these animals was slower than those receiving the other treatments, as shown by the high number of errors made even on the fourth day of testing in Lashley III maze. With respect to working memory, the animals receiving this treatment also failed to recognize the sample object, because in the presence of sample and novel objects, the animals explored both equally (mean discrimination index $=.5$ ).

Changes in the light/dark cycle made in this study didn't show effects on cognitive functions. Just as with constant lighting, circadian rhythms still occur, it may be 


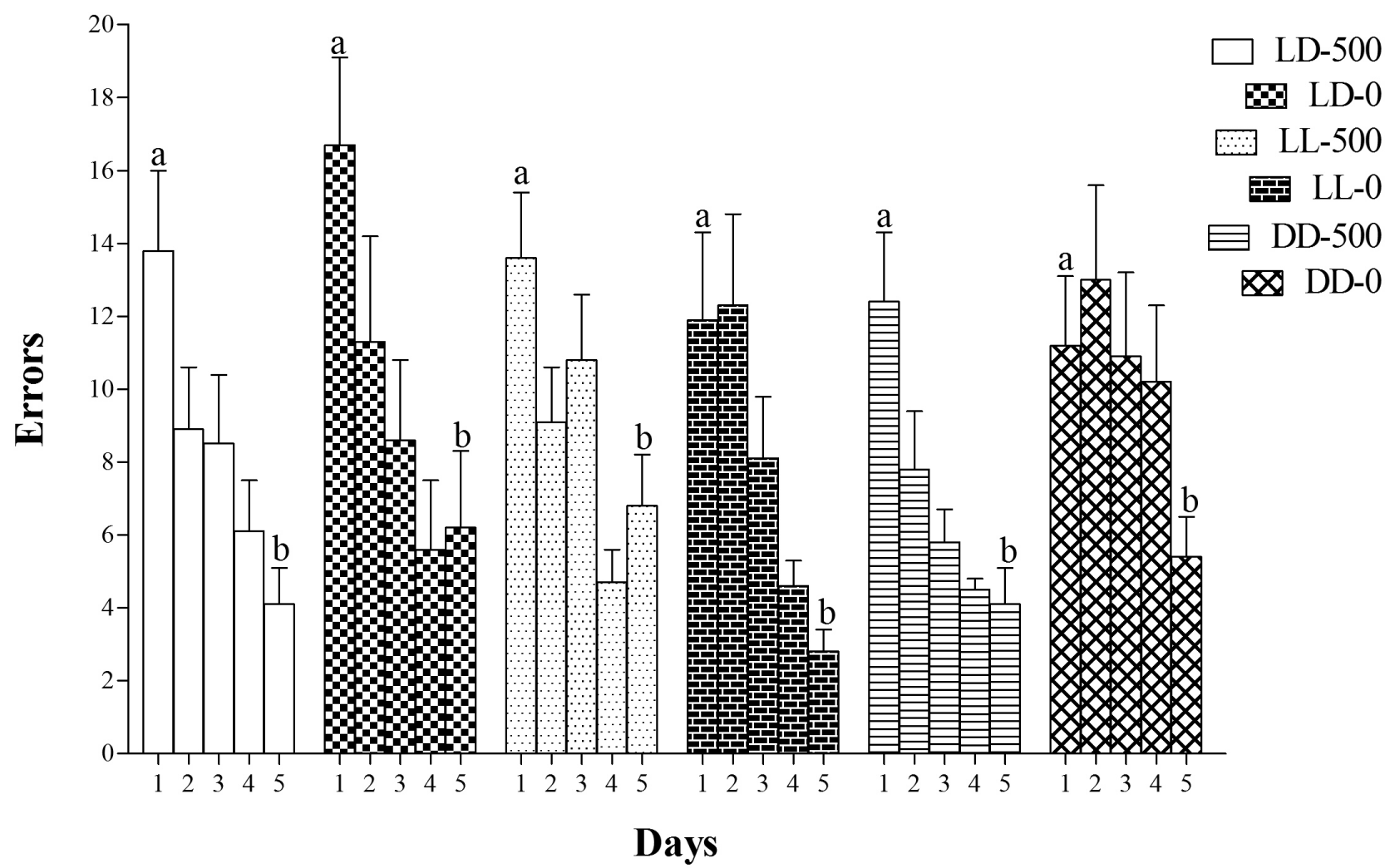

Figure 2. Means \pm S.E.M. of the number of errors made by animals receiving treatments LD-500, LD-0, LL-500, LL-0, DD-500, or DD-0, and subjected to the Lashley III maze for five days. The letters (a) and (b) indicate $\mathrm{p}<.05$ between days 1 and 5 .

that the methodology did not record significant changes in animal performance on learning and memory tests, since these were performed at the same time with all treatments. As shown by another study ${ }^{17}$, Wistar rats maintained on 11:11 h light/dark cycle and darkness constant don't show differences of performance in ORT. Unlike the observation by another study ${ }^{3}$, who conducted testing during both the light and dark phase, and found that mice learn better during the light phase.

Light intensity during the behavioral tests also didn't show a significant effect, as has been verified elsewhere ${ }^{18}$ for memory and learning in rats subjected to different lighting conditions. This could possibly be due to the short duration of exposure of the animals to different light intensity (500 or 0 lux), whereas in Lashley III maze the animals were exposed for up to five minutes, and in ORT for 10 minutes and 30 seconds, to either 0 or 500 lux light intensity.

The combination of constant dark in the housing room and testing performed at 0 lux, in other words con- tinuous darkness throughout the experiment, impaired cognitive functions. Under these conditions, it is possible that the animals have higher concentrations of melatonin than the others, as verified in Wistar rats ${ }^{19}$. This hormone inhibits Long-term potentiation (LTP) in the hippocampus $^{7,19}$ and in the cortex ${ }^{9}$ in rodents. Thus, this hormone can impair learning in animals through inhibition of LTP, since Lashley III maze, beyond what is essentially a test of

Table 2

Means \pm S.E.M. of the discrimination index of treatments $L D-500, L D$ $0, L L-500, L L-0, D D-500$, and DD-0 in the object recognition task

\begin{tabular}{cc}
\hline Treatment & mean \pm SEM \\
\hline LD-500 $(\mathrm{n}=8)$ & $.67 \pm .04$ \\
LD-0 $(\mathrm{n}=9)$ & $.57 \pm .05$ \\
LL-500 $(\mathrm{n}=10)$ & $.60 \pm .04$ \\
LL-0 $(\mathrm{n}=10)$ & $.64 \pm .04$ \\
DD-500 $(\mathrm{n}=10)$ & $.57 \pm .04$ \\
DD-0 $(\mathrm{n}=10)$ & $.50 \pm .04$ \\
\hline
\end{tabular}

$\mathrm{n}=$ number of individuals 
learning, requires some type of long term memory ${ }^{20}$ and this kind of memory involves the LTP ${ }^{21}$.

Another action of melatonin is that it causes an increase in concentration of the inhibitory neurotransmitter Gamma-aminobutyric acid (GABA) in the rat hypothalamus, cerebellum and cortex ${ }^{22}$. Thus, it is possible that melatonin caused an increased concentration of GABA in the prefrontal cortex, the region responsible for working memory ${ }^{23}$, in mice receiving treatment DD-0. As a result, there was likely inhibition of electrical activity of the neurons in this region, producing impaired working memory in these animals, which would explain the deficit in object recognition.

The neurotransmitter serotonin may also act upon cognitive functions. Just as the animals kept in continuous darkness probably have higher concentrations of melatonin, so they also likely have lower levels of serotonin; because serotonin is converted to melatonin in the pineal gland when it is dark $^{24}$. Reductions in serotonin are known to affect working memory ${ }^{25,26}$ and administration of certain types of serotonin receptor prevent loss of memory and facilitate learning ${ }^{27}$. Thus, the deficits observed in learning and working memory by animals receiving treatment DD-0 could also be due to low concentrations of serotonin. The contrary also possibly occurred in animals receiving the other treatments, where higher concentrations of serotonin might have helped their cognitive processes.

Another factor that could produce deficits in cognitive function would be an increase in the hormone corticosterone caused by stress, because it negatively affects learning and memory processes ${ }^{28}$. Constant darkness changes the rhythm of this hormone, but its amplitude remains normal ${ }^{29}$. Thus, the loss of cognitive functions observed in animals kept in continuous darkness probably wouldn't be influenced by corticosterone.

\section{CONCLUSION}

To sum up, continuous darkness impaired learning and working memory in Swiss mice, but the molecular mechanisms causing this effect are uncertain. Thus, it is necessary that further studies be done, with dosage of hormones, and measurements of histochemical and mo- lecular markers, and levels of activity in the hippocampus and prefrontal cortex under different lighting conditions.

\section{ACKNOWLEDGMENTS}

Thanks to Federal University of Juiz de Fora and Coordenação de Aperfeiçoamento de Pessoal de Nível Superior (CAPES) for their financial support, and Natália de Souza Trindade for her assistance with the experiments.

\section{REFERENCES}

1.Cardinali DP. Melatonin.l A mammalian pineal hormone. Endocr Rev 1981;2(3):327-46.

http://dx.doi.org/10.1210/edrv-2-3-327

2.Young MW. Life's 24-hour clock: molecular control of circadian rhythms in animal cells. Trends Biochem Sci 2000;25(12):601-6.

http://dx.doi.org/10.1016/S0968-0004(00)01695-9

3.Chaudhury D, Colwell CS. Circadian modulation of learning and memory in fear-conditioned mice. Behav Brain Res 2002;133(1):95-108.

http://dx.doi.org/10.1016/S0166-4328(01)00471-5

4.Gerstner JR, Yin JC. Circadian rhythms and memory formation. Nat Rev Neurosci 2010;11(8):577-88.

http://dx.doi.org/10.1038/nrn2881

5.Devan BD, Goad EH, Petri HL, Antoniadis EA, Hong NS, Ko CH, et al. Circadian phase-shifted rats show normal acquisition but impaired longterm retention of place information in the water task. Neurobiol Learn Mem 2001;75(1):51-62.

http://dx.doi.org/10.1006/nlme.1999.3957

6.Walton JC, Chen Z, Weil ZM, Pyter LM, Travers JB, Nelson RJ. Photoperiod-mediated impairment of long-term potention and learning and memory in male white-footed mice. Neuroscience 2011;175:127-32.

http://dx.doi.org/10.1016/j.neuroscience.2010.12.004

7.Cao XJ, Wang M, Chen WH, Zhu DM, She JQ, Ruan DY. Effects of chronic administration of melatonin on spatial learning ability and long-term potentiation in lead-exposed and control rats. Biomed Environ Sci 2009;22(1):70-5. http://dx.doi.org/10.1016/S0895-3988(09)60025-8

8.Manda K, Anzai K, Kumari S, Bhatia AL. Melatonin attenuates radiationinduced learning deficit and brain oxidative stress in mice. Acta Neurobiol Exp (Wars) 2007;67(1):63-70.

9.Soto-Moyano R, Burgos H, Flores F, Valladares L, Sierralta W, Fernandez $\mathrm{V}$, et al. Melatonin administration impairs visuo-spatial performance and inhibits neocortical long-term potentiation in rats. Pharmacol Biochem Behav 2006;85(2):408-14.

http://dx.doi.org/10.1016/j.pbb.2006.09.009

10.Yoo DY, Kim W, Lee CH, Shin BN, Nam SM, Choi JH, et al. Melatonin improves D-galactose-induced aging effects on behavior, neurogenesis, and lipid peroxidation in the mouse dentate gyrus via increasing PCREB expression. J Pineal Res 2012;52(1):21-8.

http://dx.doi.org/10.1111/j.1600-079X.2011.00912.x

11.Canal MM, Mohammed NM, Rodriguez JJ. Early programming of astrocyte organization in the mouse suprachiasmatic nuclei by light. Chronobiol Int 
2009;26(8):1545-58.

http://dx.doi.org/10.3109/07420520903398542

12.Bevins RA, Besheer J. Object recognition in rats and mice: a one-trial nonmatching-to-sample learning task to study 'recognition memory'. Nat Protoc 2006;1(3):1306-11.

http://dx.doi.org/10.1038/nprot.2006.205

13.Hughes RN. Neotic preferences in laboratory rodents: issues, assessment and substrates. Neurosci Biobehav Rev 2007;31(3):441-64.

http://dx.doi.org/10.1016/j.neubiorev.2006.11.004

14.Boehm GW, Sherman GF, Hoplight BJ, 2nd, Hyde LA, Bradway DM, Galaburda AM, et al. Learning in year-old female autoimmune BXSB mice. Physiol Behav 1998;64(1):75-82.

http://dx.doi.org/10.1016/S0031-9384(98)00027-4

15.National Research Council. Guide for the care and use of laboratory animals. Washington: National Academy Press; 1996. 125p.

16.Lashley KS. Brain mechanisms and intelligence: a quantitative study of injuries to the brain. New York: Dover Publications; 1963. 186 p.

17.Neto SP, Carneiro BT, Valentinuzzi VS, Araujo JF. Dissociation of the circadian rhythm of locomotor activity in a $22 \mathrm{~h}$ light-dark cycle impairs passive avoidance but not object recognition memory in rats. Physiol Behav 2008;94(3):523-7.

\section{http://dx.doi.org/10.1016/j.physbeh.2008.03.013}

18.Bert B, Fink H, Huston JP, Voits M. Fischer 344 and wistar rats differ in anxiety and habituation but not in water maze performance. Neurobiol Learn Mem 2002;78(1):11-22.

http://dx.doi.org/10.1006/nlme.2001.4040

19.Talaei SA, Sheibani V, Salami M. Light deprivation improves melatonin related suppression of hippocampal plasticity. Hippocampus 2010;20(3):447-55. 20.Arendash GW, Sengstock GJ, Sanberg PR, Kem WR. Improved learning and memory in aged rats with chronic administration of the nicotinic receptor agonist GTS-21. Brain Res 1995;674(2):252-9.

http://dx.doi.org/10.1016/0006-8993(94)01449-R

21.Martin SJ, Grimwood PD, Morris RG. Synaptic plasticity and memory: an evaluation of the hypothesis. Annu Rev Neurosci 2000;23:649-711.

http://dx.doi.org/10.1146/annurev.neuro.23.1.649

22.Rosenstein RE, Cardinali DP. Melatonin increases in vivo GABA accumulation in rat hypothalamus, cerebellum, cerebral cortex and pineal gland. Brain Res 1986;398(2):403-6.

http://dx.doi.org/10.1016/0006-8993(86)91505-2

23.Izquierdo I, Izquierdo LA, Barros DM, Mello e Souza T, de Souza MM, Quevedo J, et al. Differential involvement of cortical receptor mechanisms in working, short-term and long-term memory. Behav Pharmacol 1998;9(56):421-7.

http://dx.doi.org/10.1097/00008877-199809000-00005

24.Arendt J. Melatonin and the pineal gland: influence on mammalian seasonal and circadian physiology. Rev Reprod 1998;3(1):13-22.

http://dx.doi.org/10.1530/ror.0.0030013

25.Bass EW, Jr., Means LW, McMillen BA. Buspirone impairs performance of a three-choice working memory water escape task in rats. Brain Res Bull 1992;28(3):455-61.

http://dx.doi.org/10.1016/0361-9230(92)90047-2

26.Porter RJ, Lunn BS, O’Brien JT. Effects of acute tryptophan depletion on cognitive function in Alzheimer's disease and in the healthy elderly. Psychol Med 2003;33(1):41-9.

http://dx.doi.org/10.1017/S0033291702006906

27.Buhot MC, Martin S, Segu L. Role of serotonin in memory impairment. Ann Med 2000;32(3):210-21.

http://dx.doi.org/10.3109/07853890008998828

28.He WB, Zhang JL, Hu JF, Zhang Y, Machida T, Chen NH. Effects of glucocorticoids on age-related impairments of hippocampal structure and function in mice. Cell Mol Neurobiol 2008;28(2):277-91.

http://dx.doi.org/10.1007/s10571-007-9180-y

29.Fischman AJ, Kastin AJ, Graf MV, Moldow RL. Constant light and dark affect the circadian rhythm of the hypothalamic-pituitary-adrenal axis. Neuroendocrinology 1988;47(4):309-16.

http://dx.doi.org/10.1159/000124930 